\title{
KELANGSUNGAN HIDUP LARVA \\ IKAN PATIN SIAM (Pangasius hypopthalmus) \\ HASIL PENETASAN TELUR YANG DIRENDAM EKSTRAK DAUN TEH
}

\author{
${ }^{1)}$ Muhlis, ${ }^{2)}$ Muarofah Ghofur, dan ${ }^{3)}$ Muhammad Sugihartono \\ Alumni Program Studi Budidaya Perairan, Fakultas Pertanian Universitas Batanghari \\ Program Studi Budidaya Perairan, Fakultas Pertanian Universitas Batanghari \\ Jl. Slamet Riyadi, Broni Jambi, 36122. Telp. +6074160103 \\ ${ }^{2}$ Email korespondensi : muarofah_ghofur@yahoo.com
}

\begin{abstract}
Activities of Patin Siam Fish Hatchery to date still experiencing several obstacles, one of the success in the cultivation of Patin Siam fish (P. Hypophthalmus) is a disease attack both in adult fish, seeds, even in the egg phase. The tea leaves contain antibacterial and fungal compounds namely tannins and flavonoids that are able to inhibit bacterial and fungal attacks. This research is expected to provide benefits to the improvement by the utilization of Tea leaf extract $(C$. sinensis) given to a Siamese patin fish egg ( $P$. Hypohthalmus) as an antibacterial in the process of hatching of patin Siam fish eggs (P. Hypohthalmus). This research activity is done in the People's Hatchery unit (UPR) know the big city of Jambi which is held for 1 month. The study uses complete random design (RAL) with 4 treatments and 3 repeats, with each treatment being: (A) concentration 0.4 $\mathrm{ml} / \mathrm{L}$, (B treatment) concentration $0.6 \mathrm{ml} / \mathrm{L},(C$ treatment) concentration $0.8 \mathrm{ml} / \mathrm{L}$, ( $D$ treatment) Concentration $0 \mathrm{ml} / \mathrm{L}$. The observed parameters are: the level of survival of the larva and the quality of water. The results of research obtained for the best treatment gained on treatment B with a percentage of $89.27 \%$. The results of water quality measurement showed that the temperature range of $270 \mathrm{C}-28 \mathrm{oC}$, pH of 7.2-8.2, dissolved oxygen acquired the 7,45-8,22 range, the carbon dioxide obtained by $0.0462 \mathrm{mg} / \mathrm{L}-0.0603 \mathrm{mg} / \mathrm{L}$, and the ammonia range during the study was $0.0140-0.0310 \mathrm{mg} / \mathrm{L}$.
\end{abstract}

Keywords :, larvae survival rate, siamese catfish, water quality

\begin{abstract}
Abstrak
Kegiatan pembenihan ikan patin siam sampai saat ini masih mengalami beberapa kendala, salah satu penghambat keberhasilan dalam usaha budidaya ikan patin siam ( $P$. hypophthalmus) adalah serangan penyakit baik pada ikan dewasa, benih, bahkan pada fase telur. Daun teh mengandung senyawa antibakteri dan jamur yaitu tanin dan flavonoid yang mampu menghambat serangan bakteri dan jamur. Penelitian ini diharapkan dapat memberikan manfaat kepada pembenih dengan cara pemanfaatan ekstrak daun teh $(C$. sinensis) yang diberikan pada telur ikan patin siam ( $P$. hypohthalmus ) sebagai antibakteri pada proses penetasan telur
\end{abstract}


Jurnal Akuakultur Sungai dan Danau Vol. 4 No. 1 Tahun 2019 Hal. 9 - 14

ikan patin siam ( $P$. hypohthalmus). Kegiatan penelitian ini dilakukan di unit pembenihan rakyat (UPR) kenali besar kota jambi yang dilaksanakan selama 1 bulan. Penelitian ini menggunakan Rancangan Acak Lengkap (RAL) dengan 4 perlakuan dan 3 ulangan, dengan masing-masing perlakuan tersebut adalah : (Perlakuan A) Konsentrasi 0,4 ml/L, (Perlakuan B) Konsentrasi 0,6 ml/L, (Perlakuan C) Konsentrasi 0,8 ml/L, (Perlakuan D) Konsentrasi 0 ml/L. Parameter yang diamati adalah : Tingkat kelansungan hidup larva dan kualitas air. Hasil penelitian yang diperoleh untuk perlakuan terbaik didapat pada perlakuan B dengan persentase sebesar $89,27 \%$. Hasil pengukuran kualitas air menunjukkan bahwa kisaran suhu $27^{\circ} \mathrm{C}-28^{\circ} \mathrm{C}$, pH sebesar 7,2-8,2, Oksigen terlarut didapatkan kisaran 7,45-8,22, karbondioksida didapatkan sebesar 0,0462 mg/L - 0,0603 $\mathrm{mg} / \mathrm{L}$, dan kisaran ammonia selama penelitian ini adalah 0,0140- 0,0310 mg/l.

Kata kunci : ikan patin siam, kualitas air, tingkat kelangsungan hidup larva

\section{PENDAHULUAN}

Ikan patin siam adalah jenis ikan yang secara taksonomi termasuk species Pangasius hypophthalmus yang hidup di perairan tropis Indo Pasific SNI (2000). Di Indonesia ikan patin mempunyai prospek yang baik dalam pemasaran, karena mempunyai nilai ekonomis yang tinggi baik pada tingkat benih sebagai ikan hias maupun pada tingkat dewasa sebagai ikan konsumsi. Sehingga banyak nya permintaan harus dibarengi dengan peningkatan produksi, peningkatan produksi hanya dapat dicapai melalui budidaya perikanan (Andriyanto et al, 2012).

Adapun salah satu penghambat keberhasilan dalam usaha budidaya ikan patin siam ( $P$. hypophthalmus) adalah serangan penyakit baik pada ikan dewasa, benih, bahkan pada fase telur. Adanya serangan penyakit yang disebabkan oleh jamur pada saat penetasan telur berdampak terhadap kerusakan telur yang menyebabkan menurunnya daya tetas. Menurut Martono dan Setiyono (2014), salah satu upaya untuk meningkatkan daya tetas telur dan kelangsungan hidup larva ikan patin dengan cara mengatasi serangan bakteri dan jamur dengan upaya pengunaan zat antibakteri dan jamur yang terdapat pada salah satu tanaman yaitu daun teh. Daun teh mengandung senyawa antibakteri dan jamur yaitu tanin dan flavonoid yang mampu menghambat seranggan bakteri dan jamur (Martono dan Setiyono, 2014).

Berdasarkan urain tersebut diatas perlu kiranya dilakukan penelitian tentang pengunaan daun teh pada proses penetasan telur dan kelangsungan hidup larva ikan patin siam guna mencegah terjadinya serangan bakteri dan jamur. 


\section{METODOLOGI PENELITIAN}

Kegiatan Penelitian Kelangsungan hidup larva ikan patin siam (Pangasius hypopthalmus) hasil penetasan telur yang direndam ekstrak daun teh ini dilaksanakan pada bulan maret sampai april 2018 di UPR (Unit Pembenihan Rakyat) kenali besar. Bahan penelitian yang digunakan adalah telur ikan patin siam, air dan ekstrak daun teh. Peralatan yang digunakan dalam penelitian ini adalah corong penetasan, bak larva, aerator, blender, saringan/kain kasa, kamera digital, pengukur kualitas air, gelas ukur, mikroskop, sendok, dan toples.

Telur yang dibutuhkan pada penelitian ini sebanyak 100 butir/corong penetasan dengan jumlah total telur yang akan digunakan sebanyak 1200 butir. Telur yang digunakan berasal dari Balai Perikanan Budidaya Air Tawar (BPBAT) Sungai Gelam Jambi. Ekstrak daun teh yang digunakan dalam penelitian ini sebanyak $0,4 \mathrm{ml}, 0,6, \mathrm{ml}$, dan $0,8, \mathrm{ml}$ pada setiap perlakuan dan 3 (tiga) kali ulangan, dengan jumlah total ekstrak yang dibutuhkan sebanyak 5,4 ml. Daun teh yang digunakan berasal dari Kabupaten Pagar Alam Provinsi Sumatra Selatan. Selanjutnya mengisi air dalam toples sebanyak 1 liter, masukkan ekstrak daun teh sebanyak konsentrasi yang berbeda pada masing-masing perlakuan dan ulangan dengan kisaran $\mathrm{PA}=0,4 \mathrm{ml} / \mathrm{L}, \mathrm{PB}=0,6 \mathrm{ml} / \mathrm{L}$ dan $\mathrm{PC}=0,8 \mathrm{ml} / \mathrm{L}$, Masukkan telur sebanyak 100 butir setiap masing-masing toples yang telah dihitung menggunakan volumetrik dan biarkan telur direndam didalam toples selama 4 menit lalu pindahkan telur kedalam corong penetasan setelah direndam dalam toples selama 4 menit.

\section{Parameter Yang Diamati}

\section{Kelangsungan Hidup Larva}

$$
\mathrm{TKH}=\frac{\text { Jumlah larva akhir penelitian }}{\text { Jumlah larva awal penelitian }} \times 100 \%
$$

\section{Kualitas Air}

Sebagai data pendukung diukur kualitas air media penetasan yang meliputi suhu, $\mathrm{pH}$, oksigen terlarut, karbondioksida dan ammonia.

Data yang diproleh selama penelitian ditabulasikan kedalam bentuk Tabel, kemudian dianalisis dengan analisis sidik ragam (anova) dan untuk mengetahui perbandingan pengaruh perlakuan terhadap pertumbuhan ikan menggunakan uji BNT dan Duncan (DNMRT) pada taraf 5\%. 


\section{HASIL DAN PEMBAHASAN}

\section{Kelansungan Hidup Larva}

Berdasarkan hasil pengamatan terhadap tingkat kelangsunga hidup larva ikan patin siam ( $P$. hypopthalmus) yang diberi perlakuan perendaman telur dengan ekstrak daun teh dengan dosis berbeda diperoleh data yang disajikan pada Gambar 1. Hasil analisis sidik ragam menunjukkan bahwa perendaman telur ikan patin dengan ekstrak daun teh dengan dosis berbeda memberikan pengaruh berbeda nyata terhadap tingkat kelangsungan hidup larva ikan patin.

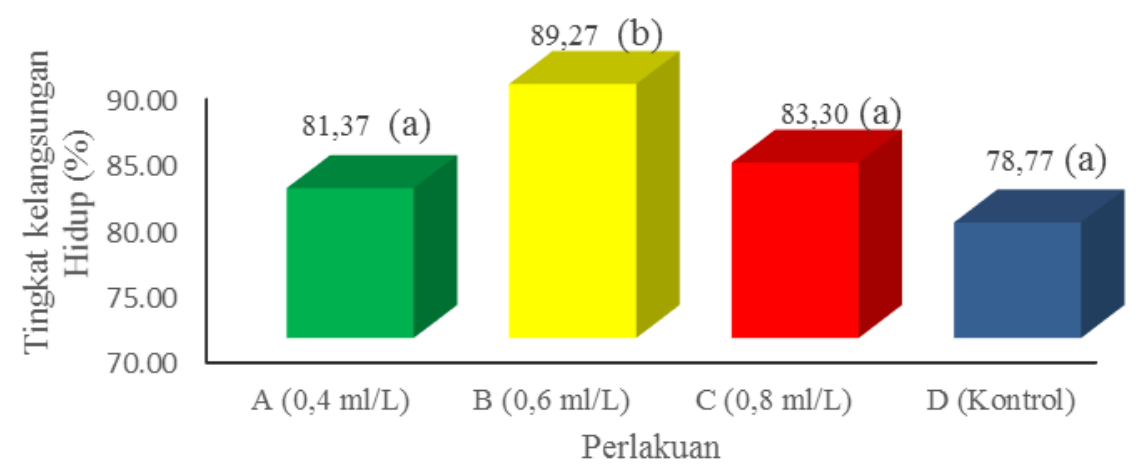

Data pada Gambar 1 menunjukkan bahwa tingkat kelangsungan hidup tertinggi terdapat pada perlakuan B yaitu sebesar $89,27 \%$, selanjutnya diikuti perlakuan C sebesar 83,30\%, kemudian perlakuan A sebesar $81,37 \%$ dan kelangsungan hidup larva terendah terdapat pada perlakuan D yaitu sebesar $78,77 \%$.

Dilihat dari hasil penelitian menunjukan kelangsungan hidup larva terendah adalah pada perlakuan D (kontrol) sebesar 78,77\%. Hal ini diduga oleh tidak diberinya ekstrak daun teh sehingga tidak terbentuknya sistem imun, sehingga adanya serangan bakteri dan jamur yang dapat menyebabkan kematian pada larva. Sementara pada perlakuan A sebesar $(81,37 \%)$ dengan dosis yang lebih rendah yaitu $0,4 \mathrm{ml} / \mathrm{L}$ diduga karena kurang optimal dalam pembentukan sistem imun, sehingga menyebabkan larva lebih mudah terserang bakteri dan jamur Hasan et al, (2016).

Tingginya kelangsungan hidup larva ikan patin pada perlakuan B $(89,27 \%)$ diduga dosis ekstrak daun teh $0,6 \mathrm{ml} / \mathrm{L}$ dianggap sebagai dosis yang optimal untuk kelangsungan hidup larva, karena daun teh memiliki kandungan senyawa beta karoten yang dapat meningkatkan sistem imun, sehingga diduga dapat meningkatkan daya tahan tubuh larva ikan dari seranggan bakteri dan jamur Hasan et al, (2016).

Sedangkan untuk perlakuan $\mathrm{C}$ dengan dosis yang tinggi $0,8 \mathrm{ml} / \mathrm{L}$ terjadi penurunan tingkat kelangsungan hidup larva yaitu $83,30 \%$. Hal ini karena adanya 
pengaruh senyawa tanin yang terdapat pada ekstrak daun teh dalam proses penetasan telur, senyawa tanin diduga bersifat asam sehingga dapat memicu untuk melunakan lapisan chorion, sehingga penetasan telur terjadi lebih cepat yang dapat menyebabkan larva menetas secara primatur, diduga karena menetas secara primatur dapat menyebabkan daya tahan tubuh larva menjadi lemah sehingga larva mudah mati (Baharudin, 2016).

\section{Kualitas Air}

Kualitas air pada penelitian ini didapatkan kisaran suhu $27^{\circ} \mathrm{C}-28^{\circ} \mathrm{C}$ Pada kisaran ini masih berada dalam kisaran optimal dalam penetasan telur dan kelangsungan hidup larva ikan (SNI, 2000). Sementara untuk pH selama penelitian ini didapatkan sebesar 7,2-8,2, nilai ini masih berada pada kisaran terbaik pada masa peerkembangan telur dan larva ikan patin (Heltonika, 2014). Untuk kisaran oksigen terlarut pada penelitian ini didapatkan 7,45-8,22. kisaran ini sudah mendukung dalam penetasan telur dan kelangsungan hidup larva. Selama penetasan telur membutuhkan oksigen terlarut yang cukup untuk penetasan telur di kisaran $5-8 \mathrm{mg} / \mathrm{l}$ (Huisman dalam Heltonika, 2014). Untuk nilai karbondioksida didapatkan sebesar 0,0462 mg/L - 0,0603 mg/L. Jumlah karbondioksida dalam air yang bertambah akan menekan aktifitas ikan dan menghambat pengikatan oksigen oleh hemoglobin sehingga dapat membuat ikan menjadi stres. Nilai ini masih dalam kondisi yang normal untuk kelangsungan hidup ikan (Dewantara, 2016). Dan untuk kisaran ammonia selama penelitian ini adalah 0,0140- 0,0310 mg/l, kadar ammonia dalam penelitian ini relatif normal dan dapat ditoleransi untuk penetasan telur dan kelangsungan hidup larva ikan. Menurut Effendi dalam Hadid et al, (2014), kandungan ammonia jika melebihi $0,2 \mathrm{mg} / \mathrm{l}$ kadar tersebut dapat menyebabkan toksik bagi beberapa jenis ikan.

\section{KESIMPULAN}

Berdasarkan penelitian Kelansungan hidup larva ikan patin siam (Pangasius hypopthalmus) hasil penetasan telur yang direndam ekstrak daun teh didapatkan kesimpulan sebagai berikut : kelansungan hidup larva terbaik adalah pada perlakuan B $(89,27 \%)$.

Disarankan penelitian Kelansungan hidup larva ikan patin siam (Pangasius hypopthalmus) hasil penetasan telur yang direndam ekstrak daun teh sebaiknya dengan konsentrasi $0,6 \mathrm{ml} / \mathrm{L}$ karena memiliki persentase terbaik. 


\section{DAFTAR PUSTAKA}

Andriyanto, S., E. Tahapari., I. Insan. 2012. Pendederan Ikan Patin di Kolam Outdoor Untuk Menghasilkan Benih Siap Tebar di Waduk Malahayu, Brebes, Jawa Tengah. Media Akuakultur Vol. 7 No. 1. 20-25.

Baharudin, A., M. B, Syakirin., T. Y, Mardiana. 2016. Pengaruh Perendaman Larutan Teh Terhadap Daya Tetas Telur Ikan Lele Sangkuriang (Clarias Gariepinus). PENA Akuatika Volume 14 No. 1. 9-17.

Dewantara, P. 2016. Pengaruh pencucian telur ikan lele dumbo(Clarias gariepinus) mengunakan ekstrak air jeruk nipis(Citrus aurantifolia) dengan dosis yang berbeda terhadap daya tetas telur. Skripsi. Jurusan Budidaya Perairan Universitas Batanghari Jambi. 54 hal.

Hadid, Yanal., M. Syaifudin., M. Amin. 2014. Pengaruh Salinitas Terhadap Daya Tetas Telur Ikan Baung (Hemibagrus Nemurus Blkr.). Jurnal Akuakultur Rawa Indonesia, 2(1) :78-92 : ISSN : 2303-2960.

Hamid, M. A. dan C. Setyowibowo. 2010. Manual Pembenihan Patin Siam (Pangasianodon hypophthalamus). Direktorat Jenderal Perikanan Budidaya. Jambi. 59 hal.

Hasan, H., E. I, Raharj., D. D, Ariyani. 2016. Pengaruh Ekstrak Daun Kemangi (Ocimum Basilicum L) Terhadap Daya Tetas Telur Ikan Lele Dumbo (Clarias Gariepinus) Yang Diinfeksi Jamur Saprolegnia Sp. Jurnal Ruaya Vol. 4. No .1. ISSN 2541 - 3155 : 18 - 23.

Heltonika, B. 2014. Pengaruh Salinitas Terhadap Penetasan Telur Ikan Jambal Siam (Pangasius Hypohthalmus). Jurnal Akuakultur Rawa Indonesia, 2(1) :13-23.

Martono, B. dan R. T. Setiyono. 2014. Skrining Fitokimia Enam Genotipe Teh. Balai Penelitian Tanaman Industri dan Penyegar. J. TIDP 1(2), 63-68.

Saanin, H. 1968. Taksanomi dan kunci klasifikasi ikan 1 dan II. Bina cipta. Bogor.

Standar Nasional Indonesia. 2000. Induk ikan patin siam (Pangasius hyphthalmus) kelas induk pokok (Parent Stock). SNI:01- 6483.1. 